Herman, J. R. Precipitation static and electrical properties of blowing snow at Byrd Station, Antarctica. (In Waynick, A. H., ed. Geomagnetism and aeronomy. Washington, D.C., American Geophysical Union, 1965, p. $22 \mathrm{I}-36$. (Antarctic Research Series, Vol. 4.) (National Research Council Publication No. 1275.)) [Study of radio noise. Deductions about charge carried by blizzard particles.]

Hoвbs, P. V. The effect of time on the physical properties of deposited snow. Fournal of Geophysical Research, Vol. 70, No. 16 , 1965 , p. 3903-07. [Explanation, in terms of growth of ice necks between particles, of changes in various mechanical properties of snow.]

Latнam, J. The electrification of snowstorms and sandstorms. Quarterly fournal of the Royal Meteorological Society, Vol. 90 , No. 383 , 1964, p. $9^{1-95}$. [Analysis of observations and explanation in terms of charge transfer due to temperature gradients.]

Latнam, J. "Elektrische" Schneestürme. Umschau, Bd. 65, Ht. I, I965, p. 28. [Summary of literature on electrification of snowstorms and its origin.]

Sommerfeld, R., and Businger, J. A. The density profile of blown snow. Fournal of Geophysical Research, Vol. 70, No. 14,1965 , p. $3303-06$. [Optical technique for measuring the density of snow suspended in air. Results indicate eddy diffusivity for snow is much larger than eddy viscosity of wind profile.]

Wakahama, G. Mizu o fukunda sekisetsu no hentai [Metamorphisms of wet snow]. Teion-kagaku [Low Temperature Science], Ser. A, Vol. 23, 1965 , p. $5^{1-66}$. [Four series of experiments, using: (1) dry compact snow at $0^{\circ} \mathrm{C}$.; (2) wet compact snow; (3) compact snow immersed in water at $0^{\circ} \mathrm{C}$.; (4) compact snow immersed in water at $0^{\circ} \mathrm{C}$. and loaded with a weight. English summary, p. 64-65.]

Wilson, A. T., and House, D. A. Chemical composition of south polar snow. Journal of Geophysical Research, Vol. 70, No. 22, 1965, p. 5515-18.

Wilson, A. T., and House, D. A. Fixation of nitrogen by aurora and its contribution to the nitrogen balance of the Earth. Nature, Vol. 205, No. 4973, 1965, p. 793-94. [Chemical analysis of South Polar snow shows o. oo5 p.p.m. N as $\mathrm{NO}_{3}^{-}$and $\mathrm{NO}_{2}^{-}$believed to be of geophysical origin.]

Woodward, R. N. Strontium-9o and cæsium-137 in Antarctic snows. Nature, Vol. 204, No. 4965, 1964, p. 1291. [Measurements of $\mathrm{Sr}$ show main influx of fission products in 1955. Cs results are more variable.]

YEN, YIN-ChAo. Effective thermal conductivity and water vapor diffusivity of naturally compacted snow. Fournal of Geophysical Research, Vol. 70, No. 8, 1965, p. 1821-25. [Experimental study of influence of air flow.]

YosıdA, Z. Yūsetsusui no sekisetsunai shintō [Infiltration of melt water in snow covers]. Teion-kagaku [Low Temperature Science], Ser. A, Vol. 23, 1965, p. 1-16. [Theoretical analysis of the ability of water to penetrate through snow cover. English abstract.]

\title{
FRANK DEBENHAM
}

It is with great regret that the Society has to announce the death of Professor Frank Debenham, Honorary Member of the Society. An obituary notice, and appreciations, will appear in the next issue of the Fournal of Glaciology. 